\title{
20. The Forbidden Gaze: The 1948 Wubarr ceremony performed for the American-Australian Scientific Expedition to Arnhem Land ${ }^{1}$
}

\author{
Murray Garde
}

\begin{abstract}
They bin make im Ubarr, everyone bin go there, make that Ubarr, and they bin look that didjeridu.

'Hey! Ubarr alright!' And everyone they bin know...I went in front. They tell me...'This thing you can't tell im kid, you can't tell im friend, you can't tell im anybody, even your wife. You find your son...you can't tell im story about Ubarr, you got to tell im what I'm telling you now. This "outside" story. Anyone can listen, kid, no-matter who, but this "inside" story you can't say. If you go in Ring-place, middle of a Ringplace, you not supposed to tell im anybody... but oh, e's nice.' ${ }^{2}$

- Bill Neidjie
\end{abstract}

\section{Introduction}

Anthropology in Australia in the early twentieth century was dealing very much with the exploration and description of the unknown. The political and cultural underpinnings of the European project to colonise and document unknown peoples and places across the globe tell us as much about Western views of science and cultural development as they do about its colonial subjects of investigation. The unknown was in a process of being revealed, rationalised, classified and collected. In his preface to Charles Mountford's Records of the American-Australian Scientific Expedition to Arnhem Land, the Australian Minister of State for Information, Arthur Calwell, described Arnhem Land as

\footnotetext{
1 Whilst this chapter discusses some aspects of ceremonial secrecy, it does not mention cultural information that is not in the public domain. In 1948, Aboriginal custodians of restricted Wubarr ceremonial knowledge had little idea that their treasured secrets were to be distributed in film and photographic form through mass media to those not entitled to view them. Even though the Wubarr ceremony is no longer performed, senior ceremonial custodians retain the right to decide which ceremonial matters or artistic depictions related to the ceremony can be made public. As a result, some artists paint Wubarr ceremony subjects from time to time, but do not make explicit in documentation details that are considered private.

2 Bill Neidjie, in Taylor, K. (ed.) 1989, Story About Feeling, Magabala Books, Broome, WA, pp. 98-101.
} 
'one of the least known parts of the earth's surface'. ${ }^{3}$ In the early to mid twentieth century, anthropologists working in Arnhem Land such as Baldwin Spencer, W. Lloyd Warner, Herbert Basedow, A. P. Elkin, Donald Thomson and Ronald and Catherine Berndt had been working their way through a staggering array of complex systems of social organisation, religious traditions and extraordinary linguistic diversity, for which Aboriginal Australia is now famous.

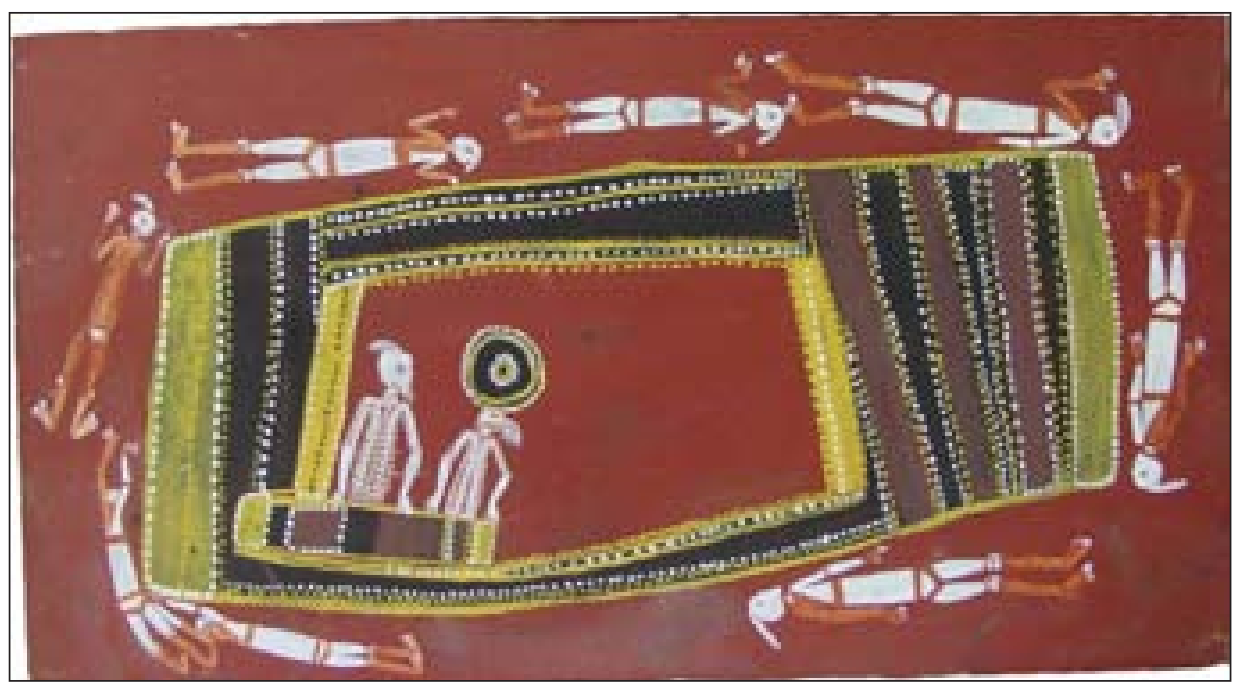

Figure 20.1 Lofty Bardayal Nadjamerrek, The Wubarr Ceremony. Earth pigment on paper, 2003

Private collection.

One of the more tangible expressions of Aboriginal religious and philosophical belief that attracted the attention of early anthropologists was the performance of religious rites and ceremonies. Major regional cult ceremonies in Arnhem Land encompass both public and secret domains of music, dance, ritual and visual arts. They celebrate and restate foundational mythologies that link the present with the origins of the cosmos and are spectacular expressions of many of the esoteric aspects of Aboriginal religion and art. Because the many religious ceremonies and rites they were witnessing were richly visual events, anthropologists in Arnhem Land frequently used still photography to document them. Until the late 1940s, ethnographic movie film was used less frequently, although both Spencer and Basedow made use of the cine-camera during their Arnhem Land expeditions. ${ }^{4}$ Indeed, the world's first ethnographic film and the

3 Mountford, C. P. (ed.) 1956, Records of the American-Australian Scientific Expedition to Arnhem Land. Volume 1: Art, myth and Symbolism, Melbourne University Press, Carlton, Vic., p. vii.

4 Cantrill, A. and Cantrill, C. 1982, 'The 1901 cinematography of Walter Baldwin Spencer', Cantrill's Film Notes, nos 37 and 38 (April); Garde, M. and Kohen, A. 2004, 'Putting Herbert Basedow back in focus: the 1928 expedition to Arnhem Land', Australian Aboriginal Studies, vol. 2004, no. 1, pp. 126-36. 
first ethnographic audio recordings made in Australia were those recorded by the Cambridge Expedition to the Torres Strait in 1898, led by anthropologist A. C. Haddon.

\section{Film and the 1948 Arnhem Land Expedition}

Charles Mountford's official Australian Government tours of the United States in 1945-46 involved the presentation of his Central Australian ethnographic films and photographs to large audiences. It was largely through the influence of these films, and the impression they left on American audiences, that National Geographic Society support for an expedition to Arnhem Land became possible. In his official proposal to the National Geographic Society, Mountford included 'the art of the body paintings, the general ethnology of the people [and] music in secular and ceremonial life' as areas of proposed anthropological research in northern Australia. ${ }^{5}$

Ethnographic film - either as unedited footage or as an assembled film documentary - had not yet developed into a fully functioning methodological tool of anthropology. Early ethnographic films were presented mostly to general audiences with the idea that they could offer an apparent transparency and immediacy beyond the abilities afforded by descriptive text. The idea, at least, was that complex rituals, dance and artistic accoutrement could be recorded in all their contextual detail for the very first time and revealed to a curious outside world. In the first half of the twentieth century, ethnographic film was frequently used for journalistic purposes. Such films operated as ethnographic reports for general consumption from the colonial front line.

Postmodern purges of anthropology have since exposed the illusion of the objective cinematographic eye, but this is not to say that ethnographic filmmakers of the mid twentieth century were always totally blind to the idea of their own culturally subjective perspectives. More recent contextualisations of early ethnographic photographic and film collections provide a better understanding of the layered meanings of these visual records. ${ }^{6}$

The 1948 Arnhem Land Expedition recorded performances of Aboriginal ceremony at Groote Eylandt and Gunbalanya (formerly Oenpelli). Ceremonial ritual and dance were recorded on movie film and still photography, and

\footnotetext{
5 Charles P. Mountford, 5 March 1945, Letter to the Chairman of the National Geographic Society Research Committee, Washington, DC, Accession File 178294, Smithsonian Institution Archives, Washington, DC.

6 For example: Batty, P., Allen, L. and Morton, J. (eds) 2005, The Photographs of Baldwin Spencer, Miegunyah Press, Carlton, Vic.; Peterson, N. 2003, Donald Thomson in Arnhem Land, (Second edition), Miegunyah Press, Carlton, Vic.; Poignant, R. and Poignant, A. 1996, Encounter at Nagalarramba, National Library of Australia, Canberra.
} 
the accompanying music and speech were in some cases recorded on Pyrox magnetic wire recorders. At Groote Eylandt, the Expedition's first research location, Mountford arranged for what he termed an 'Arawaltja' ceremony to be performed near the Expedition camp (see chapters by Jones and Thomas, this volume). The ceremony was recorded on film and described and analysed in the first volume of the Expedition records. ${ }^{7}$ Although the film documentation stands today as a rare and valuable record of complex ritual traditions, some of which are now defunct, members of the Expedition team were aware of the staged quality of their recordings, which flew in the face of their desire to record unadulterated 'primitives'. The 1948 Groote Eylandt ceremony was not performed in the usual location or at the usual time of the year. For convenience, Mountford arranged to have it performed within proximity of the base camp at Umbakumba and Expedition food was supplied to the performers. ${ }^{8}$ For the Smithsonian archaeologist, Frank Setzler, this was a disappointment and rendered the ceremony 'artificial':

How many dances were not put on that would have been used in their regular dance held at Amalipa we shall never know. One thing is certain and that is that no other Australian native ceremony has ever been recorded on cine film in color as this artificial corroboree has been. I say 'artificial' because all of it was put on for the benefit of the cameras. It would have been far better anthropologically if we could have been bystanders or photographers recording the dances and other activities during one of their annual dance ceremonies held in the regular sacred dance ground, Amalipa, during the fall [that is, late dry season] when the natives provide their own food, instead of the large tins of flour and other commodities supplied by Mountford. However, this film record is better than none. ${ }^{9}$

\section{The 1948 Wubarr: Inception and performance}

The Oenpelli ceremony recorded by the Expedition-known locally in various languages as Wubarr, Ubarr, Uwarr or Guwarr - is one of a number of major regional totemic cult ceremonies, and was in 1948 the most important in

7 Mountford, Records of the American-Australian Scientific Expedition to Arnhem Land, vol. 1, pp. 21-59.

8 Ibid., p. 39.

9 Frank M. Setzler, Diary, 1948, Papers of Frank M. Setzler, pp. 132-3, MS 5230, National Library of Australia (hereafter NLA), Canberra; also quoted in Thomas, M. 2007, 'Taking them back: archival media in Arnhem Land today', Cultural Studies Review, vol. 13, no. 2, p. 34. 
Western Arnhem Land. ${ }^{10}$ The ceremony was at one time also performed in North-East Arnhem Land, where it was referred to by the name Ngurlmarrkan alternative term also used in Western Arnhem Land today, at least by the handful of old men who retain knowledge of the ceremony. Warner, who did fieldwork in the late 1920s, believed the Ngurlmarrk was recently adopted into the ceremonial repertoire of North-East Arnhem Land and at the time was 'still being learned by the older men'. ${ }^{11}$ Warner's description of the ceremony and rituals makes it clear that this was a variation of the same ceremony performed in Western Arnhem Land. Also working in North-East Arnhem Land, Ian Keen confirmed the late adoption of the Ngurlmarrk, 'which probably originated from the Wubarr of Western Arnhem Land', but by the 1970s it was no longer being performed in the region. ${ }^{12}$ Ronald Berndt, writing in 1962, noted that '[t]o the best of my knowledge the yurlmag has not been performed in full [in NorthEast Arnhem Land] for about 20 years'. ${ }^{13}$ The last performance of the Wubarr in Western Arnhem Land is thought to have been about 1975 at Wulwunj near Mount Borradaile, $30 \mathrm{~km}$ north-west of Gunbalanya. ${ }^{14}$

A considerable amount of documentation of the Wubarr ceremony existed in 1948 when the American-Australian Scientific Expedition to Arnhem Land commissioned their ceremony at Gunbalanya. ${ }^{15}$ I do not intend to discuss here the actual content of the 1948 film because senior custodians of the ceremony in Western Arnhem Land today regard most of this as restricted, as the Kundedjnjenghmi elders Bardayal Nadjamerrek and Jimmy Kalarriya explain:

\section{BARDAYAL: Ubarr, daluk dja wurdurd kabarribekkan bad marrek kabarrinan. Marrek kabarringeybun, kabarriwakwan. \\ Women and children will hear the Ubarr [when the ceremony is performed], but they must not see it. They must not say the names [of certain ceremonial objects], they do not know about them.}

\footnotetext{
10 The name of the ceremony varies depending on the language. The Alligator rivers languages around Gunbalanya, such as Mengerr, Erre, Urningangk and Gaagadju, called the ceremony Ubarr. The Kunwinjku people who moved into the Gunbalanya region from the east use the name Wubarr. The Iwaidja equivalentfrom North-West Arnhem Land-is Kuwarr, and in Mawng on Goulburn Island it is Uwarr. Spencer also refers to the ceremonial ground as 'Goar', which is most likely a cognate with Kuwarr (Spencer, B. 1914, Native Tribes of the Northern Territory of Australia, Macmillan, London, pp. 139-41). The fact that Frederick McCarthy records the Iwaidja name of the ceremony as Gu:va: (< kuwarr) in the title of his report on the ceremony might suggest that there were Iwaidja people present at the 1948 performance. See Frederick McCarthy, Gu:va: Ceremony at Oenpelli, 1948 typescript report, Folder 135, MS 5253, NLA.

11 Warner, W. L. 1969 [1937], A Black Civilization: A study of an Australian tribe, Harper and Row, New York, p. 301.

12 Keen, I. 1994, Knowledge and Secrecy in an Aboriginal Religion, Clarendon Press, Oxford, p. 142.

13 Berndt, R. M. 1962, An Adjustment Movement in Arnhem Land, Cahiers de L'Homme, Mouton, Paris and The Hague, p. 40.

$14 \dagger$ Mindabbarl Manakgu and Sam Namarulga, Personal communication, December 2006.

15 Spencer, Native Tribes of the Northern Territory, pp. 133-44; Spencer, B. 1928, Wanderings in Wild Australia. Volume 2, Macmillan, London, pp. 765-72; Warner, A Black Civilization, pp. 301-19.
} 
KALARRIYA: Nungan Wubarr ka-warlkayindi.

The Wubarr ceremony is secret [literally, 'it stands hidden'].

Four performances of the Wubarr have been documented at Gunbalanya by anthropologists: Spencer in 1912; ${ }^{16}$ Ronald and Catherine Berndt in 1947; ${ }^{17}$ the Arnhem Land Expedition in 1948; ${ }^{18}$ and the Berndts again in 1950. ${ }^{19}$ In 1964, a Wubarr was also filmed on Goulburn Island (where the ceremony is called Uwarr) - a production made under the auspices of the newly established Australian Institute of Aboriginal Studies (now the Australian Institute of Aboriginal and Torres Strait Islander Studies: AIATSIS). ${ }^{20}$

In light of his comments about the perceived inauthenticity of ceremonies commissioned by non-Aboriginal visitors, Frank Setzler might have envied Baldwin Spencer, who had recorded the Wubarr (which he spelled Ober) near Oenpelli in July 1912. Spencer was visiting the buffalo shooter Paddy Cahill near the East Alligator River when the first stages of the ceremony were performed. ${ }^{21}$ Being in the right place at the right time allowed Spencer to witness the rites performed by Gaagadju and neighbouring Alligator rivers language groups over a number of days. His documentation, including numerous photographs, song texts, diagrams and other descriptive material, makes it clear that this was indeed a Wubarr performance. In addition to Warner's and Spencer's descriptions of the ceremony, the Sydney University anthropologist A. P. Elkin mentions the Ngurlmarrk or Wubarr ceremony in his 1938 classic, The Australian Aborigines. ${ }^{22}$ Mountford in 1948 was no doubt aware of this documentation and when the Australian Broadcasting Commission (ABC) radio journalist Colin Simpson joined the Expedition at Gunbalanya, the two men developed a plan to commission an 'aboriginal corroboree', as Simpson outlined in his book Adam in Ochre:

Radio, this side of television, is non-pictorial and so was considered near to being non-competitive [with the National Geographic magazine's exclusive rights to cover the Expedition], and, by permission, we could go in and do a 'feature' on the expedition and gather whatever else seemed interesting to describe and record in sound, such as aboriginal

\footnotetext{
16 Spencer, Native Tribes of the Northern Territory, pp. 133-44; Spencer, Wanderings in Wild Australia, vol. 2, pp. 765-72.

17 Berndt, R. M. and Berndt, C. H. 1951, Sexual Behaviour in Western Arnhem Land, Viking Fund Publications in Anthropology, New York, pp. 114-38.

18 Frederick McCarthy, Gu:va: Ceremony at Oenpelli, 1948 typescript report, Folder 135, MS 5253, NLA.

19 Berndt, R. M. and Berndt, C. H. 1970, Man, Land and Myth in North Australia: The Gunwinggu people, Ure Smith, Sydney, pp. 128-32, plates between p. 86 and p. 87.

20 Holmes, C. (dir.) 1964, Uwar of Goulburn Island [The Uwar Ceremonies of Goulburn Island], Australian Institute of Aboriginal Studies, Audiovisual Collection, DAC00037_1-7, Australian Institute of Aboriginal and Torres Strait Islander Studies (hereafter AIATSIS), Canberra.

21 Spencer, Native Tribes of the Northern Territory of Australia, p. 765.

22 Elkin, A. P. 1938, The Australian Aborigines, Angus \& Robertson, Sydney, pp. 257-8 and 260.
} 
corroboree. For years the British Broadcasting Commission had been asking the A.B.C. for corroboree sound, and the A.B.C.'s face had been red with not having any to meet the B.B.C.'s requests. ${ }^{23}$

Simpson goes on to describe how he discussed local ceremonial traditions with Mountford and, in particular, the possibility of recording the sacred sounds of secret objects used in the Wubarr. Mountford tells Simpson: 'It would be really something if you could get that corroboree on your wire-recorder-and at the same time we could get it on ours. ${ }^{24}$

Important regional ceremonies in Western Arnhem Land usually involve weeks of preparation and organisation. Various kinds of payments between people of particular social categories and ceremonial moiety groups are mandatory. They can involve food, trade goods and, most importantly, tobacco. Weeks before the rites commence, initiated youths are sent out as ceremonial messengers to invite distant groups to the ceremony. Simpson records that the 1948 Wubarr was organised by 'some old men of the Gunwinggu tribe' over a few days after he and Mountford conceived of the idea and put the request to them. ${ }^{25}$ The ceremony was also paid for by Mountford with food and tobacco - this being in keeping with the Expedition practice of remunerating Aboriginal people for services rendered, as well as the local cultural practice relating to the commissioning of religious ceremonies. ${ }^{26}$ The Wubarr rituals were usually held over a number of weeks. In August 1947, Ronald Berndt saw a Wubarr performed at Oenpelli over a period of six days. He noted that the rituals he saw 'normally extend over a much longer period' ${ }^{27}$ It is likely this 1947 ceremony had already been in progress for some days or weeks when Ronald Berndt and his wife, Catherine, arrived and conducted fieldwork (from 31 July to 12 August 1947).

The Wubarr ceremony commissioned by Mountford at Gunbalanya was reduced to a single day - Saturday, 23 October 1948 - and was therefore greatly modified for the convenience of the non-Aboriginal audience. Many Wubarr rituals take place at night, but on the last day of the ceremony, the concluding rites in the public camp where women are present, occur in the morning. ${ }^{28}$ To make it possible to photograph the ceremony, Mountford's 1948 condensed version of the Wubarr commenced in the morning and concluded in the afternoon after

\footnotetext{
23 Simpson, C. 1951, Adam in Ochre: Inside Aboriginal Australia, Angus \& Robertson, Sydney, p. 6.

24 Ibid., p. 6

25 Ibid., pp. 6-7.

26 Colin Simpson, n.d., Footnotes: The [deleted restricted word] Corroboree, Papers of Colin Simpson, Folder 135, MS 5235, NLA.

27 Berndt and Berndt, Sexual Behaviour in Western Arnhem Land, p. 138.

28 Jimmy Kalarriya, Personal communication, 2009; Berndt and Berndt, Sexual Behaviour in Western Arnhem Land, p. 131.
} 
the Expedition team had retired for a lunch break. As well as food and tobacco, Mountford went so far as to supply body paint for the ceremony. Frank Setzler's diary records the details:

October 23, 1948 - Saturday.

This was the day planned for the corroboree. About 9:30 a.m. Walker and I took our cameras and walked over to the north side at the foot of Oenpelli Hill...About 10 a.m. the natives began to paint their bodies. The first dance was a sort of preliminary one to satisfy the spirits. Monty furnished them with some of his commercial paints...I took my 4 x 5 Speed Graphic and made 24 photos up to 12:00 noon. Used K-1 filter throughout and I hope they come out OK. We had an intermission at noon...After resting in the hot breezes blowing through the tent until $2: 30$, we went back to the corroboree...Fred got the description of the various dances. He has given me a copy. ${ }^{29}$

Setzler's 'Oenpelli Hill' is known by Aboriginal people as Arrkuluk-a hill on the southern side of the township, and a traditional Wubarr ceremony ground (see Figure 20.2). Wubarr ceremonies were usually performed at the base or on the top of elevated landscapes. This longstanding tradition is reflected even today - if not geographically, then linguistically - in the major regional ceremonies that have replaced the now defunct Wubarr, such as the Kunabibi and Yabbadurruwa. To enter the restricted men's ceremonial ground from outside, one says figuratively in the Bininj Gunwok dialects of Western Arnhem Land, nga-bidbun - 'I'm going up' - regardless of whether the speaker will ascend, descend or walk across a flat area to get to the ceremony ground.

Setzler's interpretation of dances being performed to 'satisfy the spirits' is totally inconsistent with Aboriginal religion in general, let alone with what we now know about the Wubarr ceremony from other documentation. ${ }^{30}$ Such interpretations have more in common with the trope of Hollywood voodoo than they do with the ethnographic realities of the Wubarr ceremony. Indeed, as historian Martin Thomas has already pointed out, Mountford's filming direction had its own touch of Hollywood in the way he staged aspects of these ceremonies. ${ }^{31}$ Projecting an image of Aboriginal people in keeping with Mountford's primitivist views required a certain amount of stage management in the costume department. At Groote Eylandt, the performers wore too little or no clothing during ceremonial performance, so Mountford arranged for them to wear cotton loincloths that he had prepared and dyed with ink, thus creating

29 Frank M. Setzler, Diary, 1948, Papers of Frank M. Setzler, pp. 253-5, MS 5230, NLA.

30 For example: Berndt and Berndt, Sexual Behaviour in Western Arnhem Land, pp. 114-38; Berndt and Berndt, Man, Land and Myth in Northern Australia, pp. 128-32; Holmes, Uwar of Goulburn Island.

31 Thomas, 'Taking them back', pp. 25, 33. 
the illusion of nakedness while still satisfying the sensitivities of his intended audiences. ${ }^{32}$ At the Oenpelli Wubarr performance, it was the opposite problem. Offending trousers had to come off in favour of loincloths, as anthropologist Frederick McCarthy recorded in his diary entry for the day of the ceremony: 'In the beginning [of the ceremony] one man appeared in a pair of long pants and Monty made him change into a Naga loin-cloth. He yelled out-Take them off, I'm paying for this.' ${ }^{33}$



Figure 20.2 Arrkuluk, or 'Oenpelli Hill', where the 1948 Wubarr ceremony took place

Photograph by Murray Garde

The ceremonial performers, together with the group of Expedition photographers and onlookers, must have been quite a spectacle. From the diary and personal testimony of botanist Raymond Specht, who also witnessed the ceremony, we know that colour movie film was taken by cine-photographer Peter BassettSmith as well as by National Geographic Society photographer, Howell Walker. Mountford also took black-and-white movie footage of the ceremony, while Setzler and McCarthy took still photographs. One of McCarthy's images later appeared in the entry for 'Aborigines' in the 1958 edition of The Australian Encyclopaedia. ${ }^{34}$ Ray Specht's letter home to his parents describes the photographic frenzy:

\footnotetext{
32 Letter from Expedition doctor, Brian Billington, to the Director of the Australian Institute of Anatomy, Frederick Clements, 18 June 1948, A2644, National Archives of Australia, Canberra. Billington says of the loincloths: 'Hollywood has nothing on C.P.M.' (that is, Mountford). Also quoted in Thomas, 'Taking them back', p. 25.

33 Frederick McCarthy, Papers of Frederick David McCarthy, Diary 5, Yirrkala Diary No. 2 and Oenpelli, 1948, MS 3513/14/5, AIATSIS.

34 McCarthy, F. 1958, 'Aborigines', in A. H. Chisholm (ed.), The Australian Encyclopaedia. Volume 1, (Second edition), Angus \& Robertson, Sydney, p. 72a.
} 
Colin Simpson and Ray Giles have been out here doing an actuality broadcast for the A.B.C. Over the week-end, they recorded some corroborees. You have never seen anything like it - three movie cameras (Monty, Howell and Peter), two still cameras (Frank and Fred) and the A.B.C. However, in spite of this confusion, they all got some good material and appear quite happy with the results. I abandoned collecting plants on Saturday - for shame - and watched; it was a very interesting ceremony. ${ }^{35}$

Colin Simpson, replete with pith helmet and microphone, can be seen in some of the film footage as he darts in and around the Aboriginal performers making his audio recordings. The competition amongst the Expedition team members - all positioning themselves to get unimpeded photographic angles of the ceremony - is also revealed in McCarthy's descriptions of the melee:

23 Oct. An Ubar ceremony (see typed account) was held at Oenpelli Hill where the natives had a dancing ground, on the western side. Two young men were initiated. Colin Simpson made a wire recording, and bolted into the middle of the dancers all the time so spoiling the spectacle for the photographers - actually he spoilt a very beautiful and impressive performance for them... at another stage I was photographing when Bassett-Smith put his movie camera on a lower rock and spoilt my view - within a few minutes he fell off, with his camera, I said to Harney, 'Thank God, he's gone' forgetting that he might have injured himself and damaged his camera-Fortunately he didn't. ${ }^{36}$

\section{Sacred Ceremonies, Secrecy and Politics}

The recording of the 1948 Wubarr was a hybrid social scientific and journalistic endeavour that today raises the obvious issue of the cross-purposes of journalists and Aboriginal custodians of secret-sacred ceremonial knowledge. With the increasing visual and audio documentation of Aboriginal cultures, especially from the 1940s onwards, ethical issues relating to the publication of secretsacred Aboriginal cultural and intellectual property developed momentum throughout Australia. One of the more egregious incidents involving the publication of culturally restricted photographs involved T. G. H. Strehlow and Stern magazine in 1978. In an attempt to raise funds for the maintenance of his extensive collection of Central Australian material culture, Strehlow sold highly

35 Raymond Specht, Letters of Ray Specht, Extract from letter to parents dated Oenpelli, October 251948. Extract communicated by email, 6 November 2009.

36 McCarthy, Papers of Frederick David McCarthy, Diary 5, Yirrkala Diary No. 2 and Oenpelli, entry for 23 October 1948. 
sensitive and culturally restricted photographs to the German magazine Stern, which then - unbeknownst to Strehlow - sold them on to People magazine in Australia. To the shock and outrage of Central Australian communities, People published them in an article about Strehlow and Arrernte culture. ${ }^{37}$

In 1977, just a year before the Stern incident, Mountford himself was involved in a similar controversy with the publication of his book Nomads of the Australian Desert, which contained photographs of secret-sacred subjects and other information given to Mountford by Pitjantjatjara men on the condition that it remain confidential. The book was withdrawn from sale in the Northern Territory after a court injunction. ${ }^{38}$

In 1948, the Expedition team in Gunbalanya was aware of the secrecy of the Wubarr ceremony and that what they were recording was not in the public domain. Simpson in Adam in Ochre (1951) dedicates a chapter to the performance of the 1948 Wubarr, including colour photos of secret rituals and objects used in the ceremony. Details concerning the manufacture, secret names and use of these objects are fully divulged. He acknowledges that these are things that women and the uninitiated must never hear mentioned, let alone see. ${ }^{39}$ The book sold more than 50000 copies and the secrets of the Wubarr were secret no more. In addition to the publication of Simpson's book, Setzler later showed Wubarr film footage in public lectures across the United States. Whilst we have no evidence of the Aboriginal custodians of this material being consulted about this at the time, Thomas points out that Simpson did indeed explain to the Expedition's principal Aboriginal interpreter at Gunbalanya, Larry Marrawana, that the public didjeridu-accompanied songs that Simpson was recording on his Pyrox wire recorder (and unrelated to the Wubarr) would make their way into radio programs that would be broadcast across Australia. ${ }^{40}$

Simpson's main objective had been to produce an ABC radio documentary about the Wubarr for the series Australian Walkabout (see MacGregor, this volume). He produced a script and edited the audio for the production, but it was never broadcast - on the advice of Elkin. The issue at stake was not so much that the public revelation of the secret ceremonial material would distress the Aboriginal community, but rather that such distress might put future research at risk. Simpson's account of the incident can be found among his unpublished papers:

\footnotetext{
37 'Secrets of the Arandas', People Magazine, 3 August 1978, p. 22.

38 Foster and Others v. Mountford and Rigby Ltd. 14, Australian Law Reports (1977), p. 71.

39 Simpson, Adam in Ochre, p. 13.

40 Thomas, 'Taking them back', p. 32; Simpson, Adam in Ochre, p. 67. Larry Marrawana has been identified as a na-Kodjok subsection man of the Wurrik clan. His wife, Esther Maralngurra, and children (a son and a daughter) are still living at Gunbalanya and its outstations today.
} 
The recording of the [Wubarr] ${ }^{41}$ Corroboree has never gone on the air. The script was referred to Professor Elkin, head of the Department of Anthropology at the University of Sydney. He said we had recorded a 'secret' corroboree which should not be broadcast, as such a broadcast might embarrass further anthropological research in Arnhem Land if it became known to tribal leaders that such ceremonies, sacred to them, were being broadcast to the hearing of women and uninitiated young men. I never did see how that could happen and I never did agree with Professor Elkin's judgement on this matter, which the Australian Broadcasting Commission accepted and which amounted to a ban, except that Professor Elkin said he did not mind the feature being broadcast outside Australia. ${ }^{42}$

In the more recent postcolonial decades, when some anthropologists and journalists were slowly gaining awareness of the ethical implications of publishing culturally sensitive documentation, Aboriginal people themselves were gradually realising that books, photographs and films of their secretsacred ceremonies had been circulated by anthropologists and journalists in the public domain, risking exposure of these private and ritually dangerous images to their women and children. ${ }^{43}$ As Simpson's comments demonstrate, these concerns within Aboriginal communities were used as ammunition in the political rivalries amongst anthropologists and journalists in Arnhem Land and elsewhere. Mountford was unpopular, not only with many of his Expedition team members, but also with certain anthropologists of the day, particularly Elkin and his acolyte Ronald Berndt, who might have felt snubbed at being excluded from such a high-profile Expedition. Elkin often found opportunity to criticise and belittle the findings of the Expedition. ${ }^{44}$ Likewise, Mountford took delight in attacking Elkin and the Berndts in the Expedition records, casting aspersions on Ronald Berndt's well-known preoccupation with sexuality in Aboriginal culture:

Elkin and the Berndts casually mention cave paintings at Oenpelli... These writers, whose main interest appears to have been the eroticism of the cave paintings, saw little to interest them in the hundreds of colourful X-ray paintings, or the delightful groups of little Mimi running figures. The only cave paintings these writers specifically mention (already described by Spencer) is [sic] illustrated by a bark painting made by

\footnotetext{
41 The original word used here is restricted.

42 Colin Simpson, n.d., Supplement: [restricted word deleted]: Myths and a Ban, Papers of Colin Simpson, Folder 135, MS 5235, NLA.

43 Peterson, N. 2003, 'The changing photographic contract: Aborigines and image ethics', in C. Pinney and N. Peterson (eds), Photography's Other Histories, Duke University Press, Durham, NC, pp. 119-45.

44 For example, there are sniping exchanges in the correspondence between Elkin and Simpson in Simpson's personal papers, MS 5253/206, NLA.
} 
a young aboriginal. Although the writers claim that this bark painting is a replica of the original cave painting...this claim is far from being correct. ${ }^{45}$

In return, Berndt, writing in 1962, identified the 1948 Expedition as instrumental in the collapse of traditional religious life on Elcho Island. As Ian McIntosh discusses at greater length in this volume, Berndt quoted one of the leaders of the Elcho Island 'adjustment movement', David Burrumarra, who criticised the publication of photographs and films of secret ceremonies and sacred ritual objects (known as rayga in North-East Arnhem Land) by the Arnhem Land Expedition:

They [anthropologists] took pictures of our sacred ceremonies and rayga, and we got excited. Why do they do this? We understood this when Warner, Thomson and the Berndts were here. But why do they come again and again to study us? They take photographs of sacred things and show them to all the people throughout Australia and other places...We got a shock. We're not supposed to show these mareiin, these rayga to just anybody...All this made us think...Then we saw a film at the Elcho church. It was from the American-Australian Expedition, and it showed the sacred ceremonies and emblems. And everybody saw it...We've got no power to hide (these rayga): they are taking away our possessions. Are we to lose all this? Our most precious possessions...this is really our only wealth. ${ }^{46}$

Ronald Berndt's own publications on Aboriginal secret-sacred ceremony have, however, also caused distress in some Aboriginal communities in Arnhem Land over the years. The rock art archaeologist George Chaloupka recalls an incident in 1974 when he was visiting Warruwi on Goulburn Island in his capacity as an officer of the Museum and Art Gallery of the Northern Territory to investigate damage done to ceremonial sites:

In 1974, John Gwadbu, a member of the National Aboriginal Consultative Committee, acting on behalf of the Goulburn Island Council asked the visiting Senator Jim Keefe of the Federal Government to arrange for a survey and protection of their island's sites of significance. A number of important localities including ceremonial sites were recently disturbed.

The Department of Aboriginal Affairs approached the Museum and Art Gallery of the Northern Territory and on 15 December I left for Warrawi. On my arrival at Goulburn Island the Acting President of the Goulburn Island Council Phillip Magulnir told me of the people's anger on finding

45 Mountford, Records of the American-Australian Scientific Expedition to Arnhem Land, vol. 1, p. 111.

46 Berndt, An Adjustment Movement in Arnhem Land, p. 40. 
the Berndts' 1970 publication Man, Land and Myth in North Australia: the Gunwinggu People, with its explicit illustrations of ritual and sacred objects and structures in the possession of a young European woman. Phillip Magulnir asked me to take their message of disapproval for the public use of such material to the Australian Institute of Aboriginal Studies. John Gwadbu, George Winungoidj and Frank Marrali were also present. I recorded their communication.

The tape recording survived Cyclone Tracy, and in late January 1975 while in Canberra visiting family, I gave the tape to Peter Ucko [Institute Principal at the time]. I learned that Peter Ucko mentioned the Goulburn Island message at the meeting of a Publications Committee of which Berndt was a member, which apparently caused him some embarrassment. ${ }^{47}$

Again, in 2003, a copy of Ronald Berndt's book Kunapipi, ${ }^{48}$ which contains documentation and photographs of that secret cult ceremony, was discovered by Aboriginal visitors to the Jabiru town library in Kakadu National Park, which caused similar shock and concern among senior ceremonial leaders such as Jimmy Kalarriya, who asked that the book be withdrawn. ${ }^{49}$

\section{Repatriation of the 1948 Wubarr Film}

The recent repatriation of photographs and film of the 1948 Wubarr ceremony was carefully negotiated between Western Arnhem Land elders and Martin Thomas in 2005-06. Acting as an intermediary, I approached UrningangkKunwinjku language elder Jacob Nayinggul and Mengerrdji-Kunwinjku Gunbalanya traditional owner Donald Gumurdul, telling them about the existence of the film footage, which had now been transferred to DVD. ${ }^{50}$ Both men were initially cautious, but for good reason, as they explained. Some five years previously, a delegation from a southern cultural institution arrived in Gunbalanya with copies of the 1948 Wubarr on video cassette. Without first checking, and apparently with no knowledge of the cultural sensitivity of the content, a public showing of the film was arranged in the Gunbalanya Sports and Social Club - that is, the local pub. An audience of Aboriginal men, women and children gathered to watch with no knowledge of what it was they were about to see. The video commenced displaying the secret-sacred images of the Wubarr

\footnotetext{
47 Personal communication, 24 July 2009.

48 Berndt, R. M. 1951, Kunapipi, Cheshire, Melbourne.

49 Jimmy Kalarriya, Personal communication, 2003.

50 The film footage first returned to Arnhem Land in 2006 was that held in the archives of the AIATSIS Audiovisual Collection: V2451, V2453, V2954 and V2955.
} 
ceremony filmed half a century earlier. Donald Gumurdul told me that after about a minute of this, he rose from his seat, went to the video cassette player, ejected the cassette, and silently walked out of the room with the cassette in his hand. The remainder of the Aboriginal audience left the building in a state of shock and embarrassment.

Martin Thomas has detailed an account of some of the reactions of Aboriginal men in Western Arnhem Land to the 2006 film repatriation, which was handled with more caution and consultation than the Gunbalanya fiasco some years previously. ${ }^{51}$ At Kabulwarnamyo Outstation on the Arnhem Land Plateau, Kundedjnjenghmi elder Bardayal Nadjamerrek asked to view the 1948 Wubarr film after he was told of its existence. Together with other men of the outstation community, a private viewing was held, with Bardayal Nadjamerrek explaining the ceremony to younger men who had not seen a Wubarr, but had been inducted into the Kunabibi, which in the past 50 years has replaced the Wubarr as the most important large regional ceremony in Western Arnhem Land.

Bardayal Nadjamerrek conducted a lucid commentary on the ceremony and the names of the various rituals, interspersing this with exclamations of sheer pleasure in the manner of an audience at an actual ceremonial performance. His emotionally charged comments in the Bininj Gunwok language contained the kind of expressions one uses when expressing affection for a person one holds dear. The Wubarr ceremony film footage and Simpson's sound recordings were replayed simultaneously a number of times at that first session, and, at Bardayal's request, it was repeated numerous times at further morning sessions on each of the following days. Bardayal Nadjamerrek's responses were recorded as he watched and a selection of these is transcribed below.

\section{Commentary Extract 1}

BARDAYAL: La yi-na na-ngamed Djawirdda, Ngabbard yo, yo la yi-na, that old man tharran now, that old ya!

Look here, it's what's-his-name, Djawirdda, [I call him] my [classificatory]

father, yes, yes, look, that's the old man now, yes that old man.

MG: Djawirdda Balang na-Kurnumbidj?

Djawirdda, Balang skin of the Kurnumbidj clan?

BARDAYAL: Yoh, nakka yi-na!

Yes, that's him, look!

51 Thomas, 'Taking them back'. Refer also to the radio documentary: Thomas, M. (prod.) 2007, 'Return to Arnhem Land', Radio Eye, Radio National, 2 June 2007, Australian Broadcasting Corporation, Sydney. 
MG: Dja na-ngale?

Who is that now?

BARDAYAL: Kodjok! Kodjok. Oho ka-dedjbayeng Kodjok! Kodjok, narrankolo.

Kodjok [subsection name]. Oh for goodness sake, that dear man, it's Kodjok! Kodjok of the Darnkolo clan.

\section{Commentary Extract 2}

BARDAYAL: Oooo Wubarr...nakka yi-na kabani-koklewkke!

Ohhh the Wubarr, look at those two moving their heads!

Wubarr nguni-bengka ba-yimeng... Wo:rro... Ooo ngaban-djorrhbayeng!

He's telling them 'you two know this Wubarr ceremony!' Oooh, I am so moved to see these dear people.

\section{Commentary Extract 3}

BARDAYAL: Ohoho Wubarr nga-kornbayeng! Yo, ngandi-baldarrkidyo Wubarr ba ngandi-marne...yi-bekka?

Ohoho, the Wubarr, how I love this wonderful ceremony! They have come back to life for me, they have given me the Wubarr again...can you hear it?

MG: Ya.

Yes.

BARDAYAL: Ohoho...Hehe nga-djorrhbayeng Wubarr ane! Mani yi-na Wubarr ka-yo!

Hehe oh this wonderful Wubarr ceremony, how it moves me! There it is there, the Wubarr!

Other equally moving responses from other elders who viewed the film, such as Jacob Nayinggul and Thomson Yulidjiri, give some indication of the value of repatriating such culturally sensitive archival material. ${ }^{52}$ Despite the circumstances of the commissioning of the ceremony, its adaptation and manipulation for a non-Aboriginal audience and the history of the abuse of trust relating to the privacy of the film, I believe the Aboriginal community in Western Arnhem Land today still sees a place for the careful and negotiated use of restricted ceremonial film and photography. 


\section{Conclusion}

Whilst limited by their cultural sensitivity, other historical recordings of certain defunct ceremonial traditions will also become increasingly important to Aboriginal communities in the future. Such recordings were originally allowed because of an assumption that across the cultural divide, there were value and pride in sharing these ceremonial events with outsiders. In return, the expectation has always been that the privacy of the material recorded should be respected. Projects that involve the recording and archiving of the musical, ceremonial and linguistic traditions of Western Arnhem Land continue today, motivated by the same sentiments as those of the 1948 Wubarr performers: a desire to maintain certain cultural practices, teach others about them and preserve them where they are endangered.

The 1948 ceremony was clouded, however, by the cross-purposes of the groups involved. The Expedition team recorded the Wubarr ceremony in the context of scientific research and journalistic treasure hunting. As far as the Expedition team was concerned, the beliefs of the 'natives' in relation to the secret status of their rituals was at best viewed as 'quaint' and, at worst, as an impediment to scientific endeavour and career advancement. We have no record of what the senior Aboriginal organisers of the ceremony thought about the idea of performing a sacred cult ritual for a group of foreigners on a brief visit. Whatever their deliberations, they did decide to perform an attenuated version of the rites in response to the request. The Aboriginal residents of Gunbalanya usually had to deal with the disapproving attitudes of their missionary overseers when it came to ceremonial matters. In the eyes of the Aboriginal residents of Gunbalanya, the request must have clearly distinguished the Expedition team from the mission, particularly as the Anglican Church Missionary Society missionaries at Gunbalanya have always been rather intolerant of Aboriginal ceremonial ritual.

In fact, it appears that the missionaries at Gunbalanya had little idea about the nature of the Wubarr ceremony. The mission invoice issued to the Expedition for transport expenses includes the following entry for the day of the ceremony: 'Transport of personnel and gear to Oenpelli Hill for Chunday Corroboree.' The name 'Chunday' is clearly a linguistic reinterpretation of the Aboriginal pronunciation of the term 'Sunday' or 'Big Sunday', which at the time was an Aboriginal English term for large regional religious ceremonies. ${ }^{53}$ The sibilant 's' phoneme does not exist in Australian Aboriginal languages, so English words with ' $s$ ' tend to be assimilated to the Kunwinjku palatal stop. Thus, Sunday

53 In Sexual Behaviour in Western Arnhem Land, the Berndts identify the term 'Big Sunday' as a derivation of the 'Big Sandy' area cleared for the performance of ceremonial rituals: 'the term "Sandy" having suggested to the natives the appellation "Sunday", as being appropriate from a religious point of view' (p. 117). 
is more commonly pronounced Junday [fande]. When interacting with the Expedition members, the Kunwinjku referred to the ceremony by its proper name, 'Wubarr/Ubarr', as recorded in documentation, but when interacting with the missionaries, the English word 'Sunday' was used. The Gunbalanya missionaries therefore recorded the name 'Chunday' as an Aboriginal word for the name of the 'corroboree' being performed.

Simpson records that on the day after the Wubarr - a Sunday-no-one seemed interested in attending the mission church service:

The Corroboree performance was 'paid for' in food and tobacco. On the following day, Sunday, only one or two of the men who had taken part in it attended church at the Mission. They explained to Mountford that, for attendance at church, they received a tin disc, which entitled them to a ration of food from the Mission. Having received food from us, and having some of it still left, they did not see any point in going to church. ${ }^{54}$

In the 60 years since the Expedition visited Gunbalanya, the speed of cultural change in Arnhem Land has been all too disruptive and painful for most. The debate about the role of culture, change and wellbeing for Indigenous people in settler-colonial states is in full swing. In the midst of a developing openness to understand and discuss conflicting cultural values, however, it seems hardly necessary to remind ourselves that some continuity with the past can still sit positively with modernity (or ameliorate its burdens). Across much of Arnhem Land today, large regional ceremonial rites are regarded as important contributors to social cohesion. In my experience, such ceremonies represent important occasions for people from many disparate groups to work together for the purpose of achieving a sense of the 'corporate good'.

In the dry season of 2008, over a three-month period, a Kunabibi ceremony was performed at Gunbalanya. On the last evening of the ceremony, I counted more than 100 initiates from across Western Arnhem Land who were being inducted-an enormous number by usual standards. It was, however, the first Kunabibi ceremony at Gunbalanya for more than 10 years and was made possible, according to the influential and respected leader Jacob Nayinggul, only by the breathing space afforded by social policies (alcohol restrictions and welfare quarantining) instigated as part of the recent Federal Government Northern Territory National Emergency Response (commonly known as the intervention') - an unintended consequence perhaps. While the Wubarr will never be performed again in Arnhem Land, the future viability of the ceremonies

54 Colin Simpson, n.d., Footnotes: The [restricted word deleted] Corroboree, Papers of Colin Simpson, Folder 135, loose manuscript, MS 5235, NLA. 
that have replaced it is also by no means assured. Such celebratory cultural practices, however, have the potential to make a significant contribution to the psychological wellbeing of people in troubled times.

\section{Acknowledgments}

I would like to thank Martin Thomas for guidance and assistance in sharing with me the relevant archival material he painstakingly retrieved from institutions in Australia and the United States, and who first brought to my attention the archival recordings of the 1948 Wubarr. Thanks also to the anonymous referee whose comments assisted in improvements to an earlier draft of the chapter. I am also indebted to †Bardayal Nadjamerrek, †Mick Kubarkku, †Thomson Yulidjiri and Jimmy Kalarriya for sharing with me their knowledge and experience of the Wubarr ceremony — milhbayeng ngudberre! 